Ethiopian Journal of Environmental Studies \& Management 8(5): 579 - 592, 2015.

ISSN:1998-0507

doi: http://dx.doi.org/10.4314/ejesm.v8i5.11

Submitted: March 25, 2015

Accepted: July 16, 2015

\title{
TRAVEL CHARACTERISTICS AND COMMUTING PATTERN AMONG RESIDENTS OF LAGOS METROPOLIS, NIGERIA: AN ASSESSMENT
}

IDRISU, I. AND *OSOBA, S.B.

School of Management Sciences, National Open University of Nigeria

\begin{abstract}
Urban travel is not solely on travel alone, but on people's participation in activities and how this is done. The intra-city trips undertaken during weekdays comprises those which occurred from Monday to Friday which are the official working days while weekends trips comprises those undertaken on Saturdays and Sundays are off their officials duty post. Data were collected from primary and secondary sources. A survey design was adopted. The study sample consisted of 2,500 households in Lagos metropolis. . The questionnaire was administered in direct proportion to the population size of each of Local Government Areas (LGAs). Systematic sampling technique was used to select every tenth building on the identified streets. In a multi-family dwelling, random sampling was used to select one household. The household head or his/her representative was interviewed on intra-city trip patterns of the household. The data collected were analyzed using simple frequency count. It is observed that more than 95\% of residents depends on the road while relative proportion (less than 5\%) of residents depends on other modes (i.e. Rail and Ferry) of transport. Work and business trips characterized the weekdays while social, shopping and recreation trips dominated during the weekends. The distance covered in kilometer for any of the trips (work, business, social, shopping and recreation) averaged $5 \mathrm{~km}$ radius. Whereas, $35.5 \%$ of the respondents used commercial vehicles, $29.5 \%$ used private vehicles, while $20.0 \%$ used official vehicles. Another 7.8\%, 5.2\%, 2.0\% of the respondents used motorcycle, ferry and rail respectively.. The implication of this situation is the presence of too many vehicular traffic on the roads during the peak periods leading to congestion and loss of valuable man-hours in the Lagos metropolis.. It is therefore recommended that transport planners in Lagos need to develop alternative intra-city transport systems. This can be achieved through a shift to the development of other land transport systems by policy makers.
\end{abstract}

Key Words: Travel patterns, Intra-city trips, Residents, Policy makers, Lagos

\section{Introduction}

Spatial interaction in urban setting could be of at least two types namely; those that involve physical contacts like day-today movements of people and those that do not require such contact like telephoning. Particularly important in urban analysis are the day-to-day movements of people. This is because they represent both a function and a process (Ayeni, 1979, Axhausen and Garling, 1992). They are functions as long as they perform the duty of maintaining the status quo in the spatial relation of different parts of the city, while they are processes 
when changes in their volume, intensity and direction come to determine the pattern of growth and organization of the spatial structure of the city.

Human movements made possible by transport, provide vital clues to the understanding of human spatial behavior in all cities especially in developing countries where measures of telecommunication are not likely to prove of much value, given the low level of technology and the generally poor economic conditions. Transportation is very vital to urban life because it is an absolutely necessary means to an end. It allows people to carry out the diverse range of activities that made up daily life. (Filani, and Osayinmese, 1979, Filani, 1991, Filani, 1993). For the fact that cities consist of spatially separated, highly specialized land uses such as, food stores, hardware stores, banks, drug stores, hospitals, libraries, schools, post offices and so on, people must travel if they want to obtain necessary goods and services.

Worldwide, urban travel takes place when inhabitants of urban centres carry out their different activities in different places whether by necessity or by choice. Studies (Ayeni, 1974; Adeniji, 1981; 1998; Ojo, 1990) have shown that in general, people tend to travel in order to obtain access to a variety of other people, services and facilities that are not available at the origins of their journeys. To what extent, how far and by what means they travel is a result of a complex interaction of socio-economic, political and physical factors (Adeniji, 1991). The nature and degree of influence of these factors however vary from city to city and even within a given urban centre (Hausa and Schwab, 1987, Gordon et al., 1988, Rimmer, 1986 White 1990; Garling, T. and Colledge, R.G, 1994, Bhat and Koppelman, 1999).
Owen (1987) noted that "mobility has become an integral part of education, access to sports, and the amount of international trade, travel and investment". Movement patterns within the cities can be categorized as being of either short-term or long-term duration. Short-term or daily movement consists of trips involving such activities as work, shopping and recreation, whereas long-term or more permanent movement involves changing residence. .

Urbanization is the very embodiment of communication. By concentration of wide variety of creative specialists in a region of limited extent and of high connectivity, cities minimize the need for costly movement of goods and people. This is most evident in the central business areas of such large cities as the Lagos metropolis where the chief executives of major firms and public agencies have opportunities to face-to-face exchanges. These urbanization benefits are achieved, however, at the price of overcrowding, congestion, excess demands on the natural environment, and people to outlying areas. The root of this dilemma (the need for specialized interaction, information, the desire for "elbow now" and amenity) is in part the product of temporal and spatial constraints on human behaviour.

In urban transportation, the movements of people as they go about their daily activities are of great concern (Giuliano, 2001). Thus, urban transport studies are concerned with what people do, as well as where, how and when they do it and also what choices and constraints lie behind the "what", "where", "how" and "when" patterns of behaviour (Barber, 1995; Hanson, 1995). In other words, urban travel is not solely on travels alone, but on people's participation in activities and how this is done. 
Lagos metropolis is being considered as a study area because it has an increasing demand of intra-city travel pattern. .This study assessed travel characteristics and commuting pattern among the urban residents in the Lagos metropolis and to enable urban transport policy makers to understand the trip pattern characteristics of urban residents in the Lagos Metropolis.

\section{Methodology}

Both primary and secondary data were used for this research work. Primary data was collected through the use of structured questionnaires administered on the urban metropolitan residents in order to determine their socio economic characteristics, such as income, occupational status, age, marital status, household size, travel pattern. Secondary data, was gathered from relevant literature, and journal articles. The estimated number of households which was $3,232,084$ was taken for the population size, in order to determine the sample size, Bruton (1975) and Neuman (1994) recommended sample sizes between $10 \%$ and $1 \%$ for population areas of under 50,000 and 1 million respectively. However, Olokesusi (1994), Solanke (2004) and Havlicek, (1985) utilized a sample size of less than $1 \%$ in their studies. In light of these, a sample size of $0.08 \%$ of questionnaires was administered while 2,500 questionnaires were returned. In order to determine the number of households to be sampled in each of the Local Government Areas (LGAs) that constituted Lagos Metropolis, the calculated percentage $(0.08 \%)$ was multiplied with the estimated number of households in each Local Government Area (LGAs)

One type of sampling method was considered appropriate in the study. This is the Simple Random method. In each of the neighborhoods surveyed, random sampling was used to select the number of identified streets and it was also used to distribute the questionnaire among the households in each of the neighborhoods surveyed. In case of multi-family unit, one household was interviewed while random sampling was used to select samples of number of household buildings in which target respondents reside.

The questionnaire was structured into two parts, sections A and B. The first part considered the socio-economic characteristics of the respondents. The second part of the questionnaire dealt with the travel and activity pattern of urban residents. The information requested covered the details characteristics of the household trips for different purposes and for different days of the week. The basic question here included the mode-choice, purpose of trip, time spent on the journey and trip length. All the possible trips were divided into five purposes namely, work, shopping, recreation, social, and business trips. In collecting this information on travel activities, the questionnaire was given to urban residents for a week (Monday-Sunday). Thus, the questionnaire served as a self-administered travel diary and it was later collected after the seven days of a week.

Urban residents were requested to construct their urban trips within the one week. The choice of a full week was to be able to cover the totality of trips made by people both on weekdays and weekends. The reason for giving them the questionnaire to fill and record their trips activities for a week was to collect information from people while it was still fresh in their memory, thus enhancing the accuracy of the information. The questionnaire survey covers urban residents on household basis. A household is defined 
as persons living under the same roof and eating from the same pot. Following the works of Ogunjumo (1986), Oyesiku (1990), and Dimitriou (1995), household is a well-known key decision-making unit for the general.

Description of residents' daily travel characteristics provides considerable insight into the quality of life experienced, the extent of similarities and variations in their commuting patterns among different areas within the Lagos metropolis.

\section{Result and Discussion}

Characteristics of Intra-City Journeys of Residents in Lagos Metropolis

Following the works of Olayemi (1977), Barber (1995), Hanson (1995) and Solanke (2004), the four measures of trips characteristics chosen are namely, departure time, arrival time, mode of transport and trip length for each intra-city journey purposes. Trip purpose analysis is necessary for an in-depth knowledge of the aggregate patterns of intra-city travel. Such analysis revealed the structure of the movement by households and the different land uses to which certain proportion of the aggregate journeys are directed. The total numbers of trips made in the entire Lagos metropolis during the survey period was 24,388 . With these, trips to work accounted for $44.3 \%$ while those to business activities constituted $33.4 \%$. Thus journeys to work places and the trips in the area accounting for more than two thirds of all trips. These two were followed by social activities (9.6\%), shopping activities (7.9\%) and recreation activities which accounted for about $(4,9 \%)$. Simple frequency count was used to analyzed the data collected.

\section{Work Trip}

Table 1 shows the characteristics of intra-city work trips in Lagos metropolis. In examining the table, the emphasis was on the similarities and variations in departure and arrival time, modal split and length of trips of workers in all the fifteen Local Government Areas that constitute Lagos metropolis. From table 1, the residents who are workers in all the fifteen Local Government Areas that constitute Lagos metropolis have substantial proportions of work trips peak between 6.01am and 6.30am. High proportion of work trips peak period are made in Somolu (74\%) followed by Kosofe (73\%), Oshodi-Isolo (72\%), EtiOsa (72\%), Alimosho (71\%), Mushin (70\%), Agege (70\%), Surulere (69\%), Ifako-Ijaye (69\%), Apapa (69\%), AmuwoOdofin (66\%), Ojo (63\%), Ikeja (62\%), Lagos-Island $(61 \%)$ and Lagos-Mainland $(60 \%)$.

This may be because the earlier take-off of workers in all the fifteen Local Government areas might not be unconnected with the chaotic traffic situation in Lagos metropolis and their bid to get to work on time. Similarly, where there was low proportion of workers set-out between 6.01 and 9am or beyond, we have workers who are made up of traders and other workers in the informal sector with no definite time for commencing their daily activities.

The after-work journey, table 1 shows that residents who are workers in all the fifteen Local Government Areas that constitute Lagos metropolis account for $80 \%$ of workers who return home late between $6.31 \mathrm{pm}$ and $9.30 \mathrm{pm}$ every working day while the remaining $20 \%$ account for workers who return home early between $3.30 \mathrm{pm}$ and $6.30 \mathrm{pm}$ every working day. From the above, it is very clear that the variation in the nature of residents' job, especially with those who work in the private sector makes it imperative for them to arrive home late while those who work in the public sector 
(especially civil servants) return home earlier.

From the table, it is generally observed that the reason for returning home late by the residents may be as a result of the delay necessitated by the chaotic traffic situation in Lagos metropolis.

The modal split for work trips, in order of importance, across the Lagos metropolis are: commercial vehicles, private vehicles, official vehicles, motorcycles, Rail and Ferry. Table 1 below shows that the highest proportion (between $32 \%$ and $61 \%$ ) of workers in all fifteen Local Government Areas that constitute Lagos metropolis made use of commercial vehicles, followed by private vehicles (between $17 \%$ and $36 \%$ ) of workers; official vehicles (between $13 \%$ and 26\%); motorcycles (between $1 \%$ and $19 \%$ ) of workers while the Rail and Ferry have the lowest proportion of (between $1 \%$ and $3 \%$ ) of workers and (between 0 and 2\%) of workers respectively.

The distance in kilometer from the table above shows that there was variation in the distance workers had to travel before getting to their various places of work in all the fifteen Local Government Areas that constitute Lagos metropolis. Over $60 \%$ of workers who travel over a distance of between 15.1 and $30 \mathrm{~km}$ to work are in the Local Government Areas such as Agege, Ojo, Amuwo-Odofin, Alimosho, Kosofe, Ifako-Ijaye, Oshodi-Isolo, Somolu, Mushin, Surulere while the remaining proportion declines gradually with decreasing distance (between 5 and $15 \mathrm{~km}$ ) from home. The workers in these categories were those in the local government areas such as Apapa, Eti-Osa, Ikeja, Lagos-Island, and Lagos Mainland.

The above can be explained by the proximity of the commercial centres and industries to the workers in the Lagos metropolis.

\section{Business Trip}

Table..2 shows the characteristics of intra-city business trips in Lagos metropolis. From the table, the emphasis was on the similarities and variations in departure and arrival time, modal split and length of trips of workers in different urban centres of Lagos metropolis. From the table.2, in the same manner, the highest proportion of workers in all the fifteen Local Government Areas of Lagos metropolis make their trips in the peak period between 6.01am and 6.30am of every working day and such workers are in the Local Government Area such as Somolu with the higest proportion (78\%), followed by Oshodi-Isolo (75\%), Mushin (73\%), Ifako-Ijaye (73\%), Surulere (71\%) Alimosho (71\%) Kosofe (71\%) LagosIsland (70\%), Eti-Osa (70\%), Lagos Main Land (69\%), Amuwo-Odofin (69\%), Agege (69\%), Apapa (69\%), Ojo (65\%) and Ikeja $(64 \%)$.

This could be attributed to the fact that residents in the business category in Lagos metropolis leave home early as a result of the delays usually encountered on their way due to traffic congestion. The relative proportion of residents within the business category that set-out between 7.01 and 9am or later could be explained by the proximity of their business activities to their homes.

In the same manner, like work trips, business trips show that $80 \%$ of residents who engage in business activities arrive home late between $6.31 \mathrm{pm}$ and $9.30 \mathrm{pm}$ or thereafter on every business day while the remaining $20 \%$ belongs to those who return home earlier between $4.31 \mathrm{pm}$ and $6.30 \mathrm{pm}$ on every business day.

The above could be attributed to the type of business activities being engaged in by the residents. The study further shows 
that those who arrive home late must have done so as a result of traffic hold up which occur on daily basis in every part of Lagos metropolis.

The modal split for business activities in the Lagos metropolis reveals the use of Commercial vehicles, private vehicles, motorcycles, rail and ferry in the order of importance in the various urban centres. The study further shows that commercial vehicles and private vehicles carry substantial proportion of over $80 \%$ or residents who engage in business activities in each of the fifteen Local Government areas that constitute the Lagos metropolis.

The distance in Kilometer for business trips reveals that $70 \%$ of residents who engage in business activities in each of the fifteen Local Government Areas that constitute Lagos metropolis do not travel over a long distance, like the case of work trips, whose travel distance is between 5 and $20 \mathrm{~km}$. The remaining $30 \%$ of residents who engage in business activities do travel a long distance, between 20.1 to $30 \mathrm{~km}$ or beyond.

As observed in tables 1 and .2, work and business trips dominate the weekday travels. However, their characteristics show that work and business trips have their peak periods between 6.01am and 6.30am, unlike other trips. These findings confirm the remarks made by Olayemi (1977) and Bawa-Allah (2006) that Lagos metropolis is where both work and business journeys have their peak between 6.01 and 6.30am.

\section{Social Trip}

On the other hand, in comparison with other trips earlier discussed, (that is the work and business trips), the table. 3 for social trip shows that the residents in each of the fifteen Local Government Areas that constitute the Lagos metropolis engage in social travels at different times of the day.
However, the table reveals that $80 \%$ of the residents in each of the Local Government Areas engage in social trips between 8am and 12 noon and $12.01 \mathrm{pm}$ to $5 \mathrm{pm}$ while the remaining $20 \%$ of residents in each of the fifteen Local Governments Areas made their social trips between $5 \mathrm{pm}$ and late in the day.

The after-social trip journey shows that low proportion (less than 25\%) returns home earlier than $5.01 \mathrm{pm}$ every day in each of the fifteen local Government areas while the largest proportion (over 70\%) returns home later between $5.01 \mathrm{pm}$ and late in the night from their social trips.

The modal split for social travel is similar to other journey purposes with use of commercial vehicles, private vehicles, motorcycles, Rail and Ferry in order of importance in the various urban centres of Lagos metropolis. In the same manner, the study reveals that commercial and private vehicles carry substantial proportion (over $80 \%$ ) of residents who engage in social trips while the remaining low proportion $(20 \%)$ of residents who engage in social trips make use of other modes (motorcycle, Rail, and Ferry) in each of the fifteen Local Government Areas.

The distance in kilometers of social trips reveals that residents in each of the fifteen Local Government Areas engage in social travels at different distances each day. However, as shown in table.3, high proportion (over $75 \%$ ) of residents travels between 5 and $20 \mathrm{~km}$ each day while the remaining low proportion (less than 25\%) of residents travels between 20.1 and $30 \mathrm{~km}$ everyday in each of the fifteen Local Government Areas of Lagos metropolis.

\section{Shopping Trip}

The table.4 reveals that shopping activities occur throughout the day in all urban centres while the residents engage in this trip at earlier period of the day. 
However, the study shows that substantial proportion (of over 80\%) of residents engage in shopping trips between 12noon and $4 \mathrm{pm}$ in each of the fifteen local Government areas while the remaining low proportion (less than 20\%) of residents engage in shopping travels between $4.01 \mathrm{pm}$ and beyond everyday in each of the fifteen Local Government Areas of Lagos metropolis. Conversely, the residents' return journey from shopping is at later in the day and this has high proportion (over $60 \%$ ) of residents that engage in shopping activities while the remaining (less than $20 \%$ ) of residents that engage in shopping activities return home earlier in each of the fifteen local Government areas.

In the same manner, table.. 4 reveals that the modal split for shopping journeys is not different from other journey purposes with the use of commercial vehicles, private vehicles, official vehicles, motorcycles, Rail and Ferry in order of importance in each of the fifteen local Government areas. The study reveals that commercial and private vehicles carry substantial proportion (over 70\%) of residents who engage in shopping trips while the remaining low proportion (less than $30 \%$ ) of residents who engage in shopping travels in each of the fifteen Local Government Areas is carried by rail and ferry.

The distance in kilometers of shopping travels in each of the fifteen local Government areas shows the desire of the substantial proportion (over 70\%) of residents to do shopping activities within $15 \mathrm{~km}$ radius of their residences while the remaining low proportion (less than 30\%) of residents who desire to do shopping activities extend their travels beyond the $20 \mathrm{~km}$ radius.

\section{Recreation Trip}

The analysis of recreation trips characteristics reveals that like shopping trips, there is a level of uniformity in the departure time for this journey purpose in each of the fifteen local Government areas. However, the study shows that higher proportion (over 60\%) of residents engage early in recreational trips between 11am and $4 \mathrm{pm}$ each day while the relative proportion (less than 30\%) of residents engage in recreational trips late between 4.01 and later in the day in each of the fifteen Local Government Areas of Lagos metropolis. The return journey of recreational trips shows that $80 \%$ of residents who engage in recreation activities travel home late between 4.01 and late in the day while the relative proportion of $20 \%$ of residents who engage in recreation trips returns home early in the day in each of the fifteen Local Government Areas.

The study reveals that the modal split for recreational trips is not different from other journey purposes with the use of commercial vehicles, private vehicles, official vehicles, motorcycles, Rail and Ferry. The table.5 shows that higher proportion (over $75 \%$ ) of residents make use of commercial and private vehicles for recreational trips while relatively proportion (less than 25\%) of residents make use of official vehicles, motorcycles, Rail and Ferry in each of the Local Government Areas that constitute Lagos metropolis.

Table 5 shows that recreation trips take place at varying distances from homes in each of the local Government areas. However, the study reveals that substantial proportion (over 70\%) of residents travel a distance of less than 15 kilometer radius of 
their residences while relatively proportion (less than 30\%) of residents engage in recreational trips of distances of over 20kilometers radius of their residences in each of the fifteen local Government areas that constitute Lagos metropolis.

\section{Conclusion}

Generally, the study reveals detailed characteristics of each of the trip types on the basis of four features, namely: departure time, arrival time, model of travel and distance in kilometers. The regular patterns of journeys for work and business have similar opening and closing hours. The study shows that 6.01am - 6.30am and $6.31 \mathrm{pm}-8.30 \mathrm{pm}$ constitute the morning and afternoon peak periods respectively for the work and business trips in each of the fifteen Local Government areas that constitute the Lagos metropolis.

However, the regular pattern of journeys for shopping, and recreational trips reveals a different pattern of trips. The study shows that the residents travel for shopping and recreational activities before 12 noon and return later after $5 \mathrm{pm}$ every day while the residents depart for social activities at $8 \mathrm{am}$ and return home later after $5 \mathrm{pm}$ every day.

In the area of the modal split, the study reveals that the majority of residents in each of the fifteen local Government areas make use of similar modes of transport which are commercial vehicles, private vehicles, official vehicles, motorcycles, rail and ferry to their various trip purposes. However, it is observed that more than $95 \%$ of residents depend on the road while relative proportion (less than 5\%) of residents depends on other modes (i.e. Rail and Ferry) of transport. .

The study reveals that there is variation in distance in kilometers travelled by residents to the various journeys of purpose in each of the fifteen Local Government Areas in Lagos metropolis. The distance in kilometers travelled by residents depends on the proximity of the area to their various journeys purpose within the Lagos metropolis. The distance in kilometers for residents that make work and business trip.

The implication of this situation is the presence of too many vehicular traffic on the roads during the peak periods leading to congestion and loss of valuable man-hours in the Lagos metropolis. It is therefore recommended that transport planners in Lagos need to develop alternative intra-city transport systems. This can be achieved through a shift to the development of other land transport systems by policy makers.

\section{References}

Adeniji, K. (1991). Urban Mobility Crisis, where do we go from here? Paper delivered at Ogun State Public Service Forum Gateway Hotel, Abeokuta.

Axhausen, K.W. and Garling, T. (1992). Activity Based Approach to Travel Analysis Conceptual Framework, Models and Research Problem Transport Reviews, 12(4): 323-341.

Ayeni, B. (1979). Concepts and Techniques in Urban Analysis Croom Helm Ltd, London.

Bhat, C.B. and Koppelman, F.S. (1999). A retrospective and prospective survey of time use research. Transportation, 26: 119-139.

Bruton, M.J. (1975). Introduction to Transport Planning Hutchinson, London.

Dimitriou, H.T. (1995). A Development Approach to Urban Transport Planning: An Indominian Illustration, Avebury, Ashgate Publishing Limited. 
Filani, M.O. and Osayinmese, I.Z. (1979). Intra-city Traffic Flow Problems in Nigeria. The Nigerian Geographical Journal, 22(1): 17-31.

Garling, T.K. and Golledge, R.G. (1994). Computational Process Modelling of household activity scheduling. Transportation Research, 28B (5): 355-364.

Giuliano, G. (2001). Urban Design, Telecommunication and Travel Forecasting. Keynote address. Texas Transportation Institute.

Gordon, P., Kumaar, A. and Ricahrdson, H.W. (1988). Beyond The Journey to work. Transportation Research, A22: 419-426.

Hausa, S. and Schwab, M. (1987). Accessibility and Intra urban travel, Environment and Planning, 735-748.

Havlicek, J.J. (1985). Impart of Solid waste disposal site on Property values. In Tolley, G.S. and Havlicek, J. (eds) Environmental Policy Solid waste. Balinger, Cambridge, Massachutts.
Oyesiku, O.O. (1990). Inter-Urban travels pattern in Nigeria. A Case Study of Ogun State, (Unpublished Ph.D Thesis University of Benin City, Nigeria).

Olayemi, D.A. (1977). Intra-City Person Travel in Metropolitan Lagos: Study of Commuting in a fast growing capital of a developing country. Geoforum, 8:19-27.

Olokesusi, F. (1994). Impact of Ring road solid waste disposal facility in Ibadan Nigeria. NISER Monograph, Series No.3.

Policy News Magazine (2001). Vol.6, No.16, April 16-22, 2001.

Solanke, M.O. (2004). Analysis of Intra-urban travel Pattern in Ogun State, Nigeria, Unpublished Ph.D Thesis, Department of Geography, University of Ibadan.

White, P.R. (1990). Inadequacies of Urban public transport systems. In Dimitriou H.T. (ed), Transport Planning for Third World Cities London Routledge pp. 85-116. 
Table 1: Characteristics of Intra-City Work Trips in Lagos Metropolis

\begin{tabular}{|c|c|c|c|c|c|c|c|c|c|c|c|c|c|c|c|c|c|c|c|c|c|c|c|c|}
\hline & \multicolumn{2}{|c|}{$\begin{array}{c}\text { Departure } \\
\text { Time }\end{array}$} & & & & & \multicolumn{2}{|c|}{ Arrival time } & & & & & \multicolumn{2}{|c|}{$\begin{array}{l}\text { Mode of } \\
\text { Transport }\end{array}$} & & & & \multicolumn{3}{|c|}{$\begin{array}{l}\text { Distance in } \\
\text { Kilometers }\end{array}$} & & & & \\
\hline & $\begin{array}{l}\text { Respond } \\
\text { in Perce }\end{array}$ & $\begin{array}{l}\text { ents } \\
\text { tage }\end{array}$ & & & & & $\begin{array}{r}\text { Resp } \\
\text { in Per }\end{array}$ & $\begin{array}{l}\text { ndent } \\
\text { entage }\end{array}$ & & & & & $\begin{array}{r}\text { Respo } \\
\text { Per } \\
\end{array}$ & $\begin{array}{l}\text { dents in } \\
\text { ntage }\end{array}$ & & & & & $\begin{array}{l}\text { ponden } \\
\text { ercenta }\end{array}$ & & & & & \\
\hline $\begin{array}{l}\text { LOCAL } \\
\text { GOVERNME } \\
\text { NT AREAS }\end{array}$ & $\begin{array}{l}\text { Before } \\
5.00 \mathrm{am}\end{array}$ & \begin{tabular}{|l|}
5.01 \\
- \\
$6 a m$
\end{tabular} & $\begin{array}{l}6.01- \\
7 \mathrm{am}\end{array}$ & $\begin{array}{l}7.01 \\
- \\
8 \mathrm{am}\end{array}$ & $\begin{array}{l}8.01 \\
- \\
9 \mathrm{am}\end{array}$ & $\begin{array}{l}9.01 \\
\text { and } \\
\text { later }\end{array}$ & $\begin{array}{l}3.30- \\
4 \mathrm{pm}\end{array}$ & $\begin{array}{l}4.31- \\
5.30 \mathrm{p} \\
\mathrm{m}\end{array}$ & $\begin{array}{l}5.31- \\
6.30 \mathrm{p} \\
\mathrm{m}\end{array}$ & $\begin{array}{l}6.31 \\
-730\end{array}$ & $\begin{array}{l}7.31 \\
- \\
830\end{array}$ & $\begin{array}{l}8.31- \\
930 \mathrm{p} \\
\mathrm{m}\end{array}$ & $\begin{array}{l}\text { Privat } \\
\mathrm{e} \\
\text { Vehicl } \\
\mathrm{e}\end{array}$ & $\begin{array}{l}\text { Officia } \\
1 \\
\text { Vehicl } \\
\mathrm{e}\end{array}$ & $\begin{array}{l}\text { Commer } \\
\text { cial } \\
\text { Vehicle }\end{array}$ & $\begin{array}{l}\text { Motor } \\
\text { Cycle }\end{array}$ & $\begin{array}{l}\text { Ferr } \\
\mathrm{y}\end{array}$ & Rail & $\begin{array}{l}\text { Belo } \\
\mathrm{w} \\
5 \mathrm{~km}\end{array}$ & $\begin{array}{l}5.1- \\
10 \mathrm{k} \\
\mathrm{m}\end{array}$ & $\begin{array}{l}10- \\
15 \mathrm{k} \\
\mathrm{m}\end{array}$ & $\begin{array}{l}15.1- \\
20 \mathrm{~km}\end{array}$ & $\begin{array}{l}20.1 \\
25 \mathrm{k} \\
\mathrm{m}\end{array}$ & $\begin{array}{l}25.1- \\
30 \mathrm{k} \\
\mathrm{m}\end{array}$ \\
\hline Agege & 2.32 & $\begin{array}{l}70.2 \\
3 \\
\end{array}$ & 20.13 & 4.23 & 2.04 & 1.05 & 14.79 & 11.21 & 12.06 & $\begin{array}{l}22.5 \\
9\end{array}$ & $\begin{array}{l}21.1 \\
1\end{array}$ & 18.24 & 20.71 & 14.30 & 50.21 & 14.78 & - & - & $\begin{array}{l}12.5 \\
6\end{array}$ & $\begin{array}{l}13.7 \\
5\end{array}$ & $\begin{array}{l}18.6 \\
0\end{array}$ & 16.21 & $\begin{array}{l}18.7 \\
6\end{array}$ & $\begin{array}{l}20.1 \\
2\end{array}$ \\
\hline Ojo & 2.26 & $\begin{array}{l}63.7 \\
9 \\
\end{array}$ & 19.21 & 6.13 & 4.97 & 3.64 & 11.78 & 14,62 & 13.82 & $\begin{array}{l}24.5 \\
1 \\
\end{array}$ & $\begin{array}{l}19.1 \\
2 \\
\end{array}$ & 16.15 & 23.20 & 13.10 & 49.79 & 13.91 & - & - & $\begin{array}{l}19.4 \\
1 \\
\end{array}$ & $\begin{array}{l}17.7 \\
9 \\
\end{array}$ & $\begin{array}{l}13.1 \\
2 \\
\end{array}$ & 10.66 & $\begin{array}{l}20.3 \\
3 \\
\end{array}$ & $\begin{array}{l}18.6 \\
9 \\
\end{array}$ \\
\hline $\begin{array}{l}\text { Amuwo- } \\
\text { odofin }\end{array}$ & 1.02 & 66.2 & 23.8 & 3.67 & 3.2 & 2.11 & 13.32 & 12.08 & 15.3 & $\begin{array}{l}20.0 \\
7 \\
\end{array}$ & $\begin{array}{l}25.0 \\
8 \\
\end{array}$ & 14.15 & 17.30 & 16.40 & 51.50 & 4.80 & - & - & $\begin{array}{l}14.1 \\
9 \\
\end{array}$ & $\begin{array}{l}13.4 \\
3 \\
\end{array}$ & $\begin{array}{l}15.5 \\
6 \\
\end{array}$ & 21.22 & $\begin{array}{l}17.1 \\
3 \\
\end{array}$ & $\begin{array}{l}18.4 \\
7\end{array}$ \\
\hline Alimosho & 1.79 & $\begin{array}{l}71.0 \\
5 \\
\end{array}$ & 17.2 & 5.12 & 2.61 & 2.23 & 13.39 & 12.13 & 20.43 & $\begin{array}{l}16.2 \\
9 \\
\end{array}$ & $\begin{array}{l}19.9 \\
7 \\
\end{array}$ & 17.79 & 18.20 & 19.20 & 58.80 & 2.60 & - & 1.20 & $\begin{array}{l}19.3 \\
2 \\
\end{array}$ & $\begin{array}{l}18,2 \\
4 \\
\end{array}$ & $\begin{array}{l}11.5 \\
1 \\
\end{array}$ & 12.51 & $\begin{array}{l}19.1 \\
1 \\
\end{array}$ & $\begin{array}{l}19.3 \\
1 \\
\end{array}$ \\
\hline Apapa & 2.21 & $\begin{array}{l}69.0 \\
3\end{array}$ & 20.79 & 4.12 & 2.80 & 1.05 & 10.56 & 15.21 & 14.79 & $\begin{array}{l}18.4 \\
1\end{array}$ & $\begin{array}{l}21.7 \\
6\end{array}$ & 19.27 & 26.10 & 26.30 & 40.20 & 1.70 & 2.31 & 3.30 & $\begin{array}{l}18.1 \\
0\end{array}$ & $\begin{array}{l}20.3 \\
1\end{array}$ & $\begin{array}{l}10.1 \\
0\end{array}$ & 14.01 & $\begin{array}{l}20.1 \\
2\end{array}$ & $\begin{array}{l}17.3 \\
6\end{array}$ \\
\hline Eti-osa & 1.37 & $\begin{array}{l}72.2 \\
1 \\
\end{array}$ & 17.09 & 5.11 & 2.13 & 2.09 & 12.86 & 14.05 & 13.33 & $\begin{array}{l}20.5 \\
3 \\
\end{array}$ & $\begin{array}{l}21.0 \\
6 \\
\end{array}$ & 18.17 & 15.30 & 23.31 & 52.49 & 8.70 & 0.2 & - & $\begin{array}{l}13.1 \\
2 \\
\end{array}$ & $\begin{array}{l}24.7 \\
9 \\
\end{array}$ & $\begin{array}{l}18.4 \\
1 \\
\end{array}$ & 19.06 & $\begin{array}{l}13.8 \\
1 \\
\end{array}$ & $\begin{array}{l}11.0 \\
3 \\
\end{array}$ \\
\hline Ifako-ljaye & 1.79 & $\begin{array}{l}69.7 \\
2 \\
\end{array}$ & 19.18 & 4.24 & 2.14 & 2.93 & 16.22 & 13.73 & 18.20 & $\begin{array}{l}17.4 \\
2\end{array}$ & $\begin{array}{l}18.1 \\
2\end{array}$ & 16.31 & 27.30 & 18.82 & 50.78 & 3.10 & - & - & $\begin{array}{l}11.4 \\
1\end{array}$ & $\begin{array}{l}14.3 \\
2\end{array}$ & $\begin{array}{l}16.1 \\
1\end{array}$ & 20.52 & $\begin{array}{l}17.3 \\
2\end{array}$ & $\begin{array}{l}20.3 \\
2 \\
\end{array}$ \\
\hline Ikeja & 1.07 & 62.3 & 27.13 & 4.01 & 3.22 & 1.75 & 8.09 & 11.23 & 18.13 & $\begin{array}{l}20.4 \\
7\end{array}$ & $\begin{array}{l}22.4 \\
1\end{array}$ & 20.21 & 36.30 & 21.10 & 32.00 & 10.60 & - & - & $\begin{array}{l}16.5 \\
8\end{array}$ & $\begin{array}{l}18.4 \\
6\end{array}$ & $\begin{array}{l}19.3 \\
2\end{array}$ & 14.32 & $\begin{array}{l}15.1 \\
1\end{array}$ & $\begin{array}{l}6.2 \\
1\end{array}$ \\
\hline Kosofe & 2.50 & $\begin{array}{l}73.5 \\
1\end{array}$ & 16.96 & 3.95 & 1.60 & 1.50 & 18.21 & 16.18 & 13.75 & $\begin{array}{l}17.4 \\
2\end{array}$ & $\begin{array}{l}18.1 \\
3\end{array}$ & 16.13 & 22.10 & 18.12 & 40.48 & 19.30 & - & - & $\begin{array}{l}12.1 \\
9\end{array}$ & $\begin{array}{l}15.1 \\
2\end{array}$ & $\begin{array}{l}18.2 \\
6\end{array}$ & 16.12 & $\begin{array}{l}20.1 \\
2\end{array}$ & $\begin{array}{l}18.1 \\
9\end{array}$ \\
\hline Lagos Island & 0.53 & $\begin{array}{l}61.7 \\
9\end{array}$ & 17.04 & $\begin{array}{l}15.7 \\
9\end{array}$ & 3.46 & 2.06 & 10.61 & 13.97 & 16.22 & $\begin{array}{l}15.3 \\
2\end{array}$ & $\begin{array}{l}21.7 \\
6\end{array}$ & 22.12 & 32,50 & 29.51 & 33.09 & 4.90 & - & - & $\begin{array}{l}15.1 \\
3\end{array}$ & $\begin{array}{l}12.2 \\
1\end{array}$ & $\begin{array}{l}20.1 \\
7\end{array}$ & 17.67 & $\begin{array}{l}16.6 \\
0\end{array}$ & $\begin{array}{l}14.2 \\
2\end{array}$ \\
\hline $\begin{array}{l}\text { Lagos } \\
\text { Mariland }\end{array}$ & 1.01 & $\begin{array}{l}60.9 \\
6\end{array}$ & 19.04 & $\begin{array}{l}14.0 \\
6\end{array}$ & 2.74 & 2.19 & 12.18 & 12.79 & 15.20 & $\begin{array}{l}16.7 \\
9\end{array}$ & $\begin{array}{l}20.0 \\
3\end{array}$ & 23.01 & 27.30 & 28.75 & 40.75 & 3.20 & - & - & $\begin{array}{l}17.3 \\
2\end{array}$ & $\begin{array}{l}19.1 \\
2\end{array}$ & $\begin{array}{l}20.5 \\
7\end{array}$ & 16.18 & $\begin{array}{l}13.4 \\
9\end{array}$ & $\begin{array}{l}13.3 \\
2\end{array}$ \\
\hline Oshodi-Isolo & 1.06 & $\begin{array}{l}72.3 \\
0\end{array}$ & 17.07 & 6.31 & 2.14 & 1.12 & 13.42 & 14.51 & 14.62 & $\begin{array}{l}20.1 \\
2\end{array}$ & $\begin{array}{l}19.2 \\
8\end{array}$ & 18.25 & 19.35 & 23.07 & 44.08 & 11.20 & - & 2,30 & $\begin{array}{l}10.1 \\
2\end{array}$ & $\begin{array}{l}13.1 \\
7\end{array}$ & $\begin{array}{l}17.4 \\
2\end{array}$ & 19.11 & $\begin{array}{l}22.1 \\
2\end{array}$ & $\begin{array}{l}18.0 \\
6\end{array}$ \\
\hline Somolu & 1.13 & $\begin{array}{l}74.3 \\
1\end{array}$ & 11.09 & 8.21 & 3.03 & 2.23 & 14.10 & 15.06 & 15.97 & $\begin{array}{l}18.3 \\
8\end{array}$ & $\begin{array}{l}19.2 \\
1\end{array}$ & 17.28 & 17.79 & 19.12 & 48.99 & 14.10 & - & - & $\begin{array}{l}11.4 \\
8\end{array}$ & $\begin{array}{l}14.1 \\
8\end{array}$ & $\begin{array}{l}16.0 \\
6\end{array}$ & 16.71 & $\begin{array}{l}21.4 \\
5\end{array}$ & $\begin{array}{l}20.1 \\
2\end{array}$ \\
\hline Mushin & 1.76 & $\begin{array}{l}70.9 \\
6 \\
\end{array}$ & 17.06 & 6.23 & 2.63 & 1.36 & 11.69 & 13.77 & 14.41 & $\begin{array}{l}21.5 \\
1 \\
\end{array}$ & $\begin{array}{l}19.1 \\
1 \\
\end{array}$ & 19.51 & 20.70 & 18.83 & 49.97 & 10.50 & - & - & $\begin{array}{l}12.0 \\
6 \\
\end{array}$ & $\begin{array}{l}14.3 \\
4 \\
\end{array}$ & $\begin{array}{l}15.0 \\
2\end{array}$ & 18.06 & $\begin{array}{l}21.0 \\
6 \\
\end{array}$ & $\begin{array}{l}19.3 \\
6 \\
\end{array}$ \\
\hline Surulere & 2.11 & $\begin{array}{l}69.7 \\
7 \\
\end{array}$ & 26.79 & 5.21 & 2.80 & 3.32 & 15.21 & 13.92 & 13.79 & $\begin{array}{l}19.2 \\
4 \\
\end{array}$ & $\begin{array}{l}18.7 \\
9 \\
\end{array}$ & 19.05 & 23.11 & 22.42 & 49.07 & 5.40 & - & - & $\begin{array}{l}13.3 \\
6 \\
\end{array}$ & $\begin{array}{l}15.0 \\
5 \\
\end{array}$ & $\begin{array}{l}15.1 \\
5 \\
\end{array}$ & 18.26 & $\begin{array}{l}21.0 \\
1\end{array}$ & $\begin{array}{l}17.1 \\
7 \\
\end{array}$ \\
\hline
\end{tabular}


Table 2 Characteristics of Intra-City Business Trips in Lagos Metropolis

\begin{tabular}{|c|c|c|c|c|c|c|c|c|c|c|c|c|c|c|c|c|c|c|c|c|c|}
\hline & Departu & Time & & & & & Arrival & ime & & & Mode o & Transport & & & & $\begin{array}{l}\text { Distane } \\
\text { Kilome }\end{array}$ & & & & & \\
\hline & $\begin{array}{l}\text { Respont } \\
\text { Percent: }\end{array}$ & its in & & & & & $\begin{array}{l}\text { Respon } \\
\text { Percen }\end{array}$ & ents in & & & $\begin{array}{l}\text { Respon } \\
\text { Peræen }\end{array}$ & ents in & & & & $\begin{array}{l}\text { Respo } \\
\text { in Per }\end{array}$ & $\begin{array}{l}\text { Idents } \\
\text { entage }\end{array}$ & & & & \\
\hline $\begin{array}{l}\text { LOCAL } \\
\text { GOVERNMENT } \\
\text { AREAS }\end{array}$ & $\begin{array}{l}\text { Before } \\
6.00 \mathrm{am}\end{array}$ & $\begin{array}{l}6.01 \\
\text { to7am }\end{array}$ & $\begin{array}{l}7.01 \\
\text { to8a } \\
\text { m }\end{array}$ & $\begin{array}{l}8.01- \\
\text { 9am }\end{array}$ & $\begin{array}{l}9.01 \\
\text { and } \\
\text { late } \\
\mathrm{r}\end{array}$ & $\begin{array}{l}4.31- \\
5.30 \mathrm{p} \\
\mathrm{m}\end{array}$ & $\begin{array}{l}5.31 \text { to } \\
6.30 \mathrm{p} \\
\mathrm{m}\end{array}$ & $\begin{array}{l}6.31- \\
7.30 \mathrm{p} \\
\mathrm{m}\end{array}$ & $\begin{array}{l}7.31 \cdot \\
8.30 p \\
\text { m }\end{array}$ & $\begin{array}{l}8.31- \\
9.30\end{array}$ & $\begin{array}{l}\text { Privat } \\
\text { e } \\
\text { vehicl } \\
\text { e }\end{array}$ & $\begin{array}{l}\text { Commerci } \\
\text { al vehicke }\end{array}$ & $\begin{array}{l}\text { Moto } \\
\mathrm{r} \\
\text { Cycle }\end{array}$ & Ferry & Rail & $\begin{array}{l}\text { Below } \\
5 \mathrm{~km}\end{array}$ & $\begin{array}{l}5.1- \\
10 \mathrm{~km}\end{array}$ & $\begin{array}{l}10 t_{0} \\
15 \mathrm{~km}\end{array}$ & $\begin{array}{l}15.1- \\
20 \mathrm{~km}\end{array}$ & $\begin{array}{l}20.1- \\
25 \mathrm{~km}\end{array}$ & $\begin{array}{l}25.1 \text { to } \\
30 \mathrm{~km}\end{array}$ \\
\hline Agege & 3.37 & 69.22 & 18.30 & 6.10 & 3.01 & 12.19 & 15.26 & 24.78 & 26.06 & 23.71 & 28.81 & 60.28 & 10.91 & - & - & 11.46 & 14.82 & 17.18 & 17.89 & 21.42 & 177.23 \\
\hline Ojo & 5.98 & 65.01 & 20.32 & 6.91 & 1.78 & 14.42 & 18.37 & 18.84 & 25.72 & 22.65 & 29.19 & 61.36 & 9.45 & - & - & 14.32 & 13.44 & 20.23 & 19.33 & 19.42 & 13.26 \\
\hline Amuwo-odofin & 3.51 & 69.81 & 19.78 & 5.30 & 1.60 & 12.87 & 15.46 & 22.88 & 27.19 & 24.03 & 26.40 & 68.12 & 5.48 & - & - & 12.62 & 13.89 & 15.15 & 20.18 & 21.61 & 16.55 \\
\hline Alimosho & 4.01 & 71.27 & 18.26 & 4.43 & 2.03 & 12.46 & 116.72 & 21.82 & 27.89 & 21.11 & 23.82 & 60.42 & 3.45 & - & 12.31 & 15.45 & 14.26 & 16.42 & 19.83 & 23.45 & 10.59 \\
\hline Apapa & 3.26 & 69.56 & 19.96 & 5.98 & 1.24 & 10.79 & 17.21 & 23.21 & 29.21 & 19.58 & 35.42 & 52.72 & 2.52 & 3.11 & 6.23 & 10.43 & 18.21 & 20.18 & 18.42 & 18.32 & 14.44 \\
\hline Eti-osa & 3.39 & 70.47 & 18.67 & 4.64 & 2.83 & 11.92 & 18.01 & 23.48 & 25.39 & 21.20 & 22.32 & 66.87 & 1.92 & 8.89 & - & 13.88 & 16.42 & 19.38 & 20.01 & 13.42 & 16.89 \\
\hline Ifako-Ijaye & 4.21 & 73.06 & 16.48 & 4.24 & 2.01 & 13.13 & 19.41 & 21.82 & 24.53 & 21.11 & 30.45 & 62.36 & 7.19 & - & - & 11.44 & 13.21 & 16.61 & 21.12 & 17.34 & 20.28 \\
\hline Ikeja & 1.02 & 64.82 & 29.03 & 3.87 & 1.26 & 10.02 & 20.12 & 20.14 & 26.43 & 23.29 & 38.12 & 55.82 & 6.06 & - & - & 13.02 & 19.13 & 21.14 & 21.89 & 14.42 & 10.40 \\
\hline Kosofe & 5.26 & 71.97 & 20.46 & 2.02 & 0.29 & 12.42 & 22.09 & 24.40 & 22,04 & 19.05 & 24.82 & 63.43 & 11.75 & - & - & 10.42 & 20.12 & 22.13 & 20.18 & 12.11 & 15.04 \\
\hline Lagos Island & 1.06 & 70.69 & 16.22 & 9.02 & 3.01 & 10.32 & 8.42 & 23.02 & 24.16 & 24.08 & 40.13 & 54.34 & 5.53 & - & - & 11.89 & 13.82 & 20.19 & 24.82 & 15.20 & 14.08 \\
\hline Lagos Mariland & 1.02 & 69.77 & 19.46 & 5.25 & 5.50 & 10.97 & 19.32 & 24.48 & 23.86 & 21.37 & 38.42 & 57.02 & 4.56 & 16.20 & 18.34 & 25.02 & 20.10 & 10.18 & 10.16 & & \\
\hline Oshodi-Isolo & 3.88 & 75.89 & 15.57 & 3.16 & 1.50 & 14.09 & 22.07 & 23.21 & 23.97 & 16.66 & 28.63 & 62.31 & 5.06 & - & 4.00 & 15.80 & 20.10 & 20.46 & 18.12 & 13.12 & 12.40 \\
\hline Somolu & 4.44 & 78.23 & 12.69 & 2.62 & 2.02 & 13.89 & 21.24 & 22.38 & 24.66 & 17.83 & 27.89 & 66.11 & 6.00 & - & - & 14.48 & 18.21 & 22.01 & 20.47 & 14.02 & 10.81 \\
\hline Mushin & 5.03 & 73.83 & 14.21 & 9.91 & 2.00 & 14.59 & 19.89 & 23.98 & 23.32 & 18.22 & 28.42 & 67.05 & 4.53 & - & - & 12.02 & 14.07 & 21.79 & 23.01 & 16.33 & 12.70 \\
\hline Surulere & 6.13 & 71.69 & 17.02 & 3.15 & 2.01 & 14.87 & 20.42 & 24.12 & 22.46 & 18.13 & 28.21 & 65.24 & 6.55 & - & - & 10.12 & 18.09 & 20.41 & 20.32 & 17.04 & 14.02 \\
\hline
\end{tabular}


Table 3 Characteristics of Intra-City Social Trips in Lagos Metropolis

\begin{tabular}{|c|c|c|c|c|c|c|c|c|c|c|c|c|c|c|c|c|c|}
\hline \multirow[b]{3}{*}{$\begin{array}{l}\text { LOCAL } \\
\text { GOVERNMENT } \\
\text { AREAS } \\
\end{array}$} & \multirow{2}{*}{\multicolumn{3}{|c|}{\begin{tabular}{l|l} 
Departure Time & \\
Respondents in Percentage
\end{tabular}}} & \multirow{2}{*}{\multicolumn{3}{|c|}{$\begin{array}{l}\text { Arrival Time } \\
\text { Respondent in Percentage }\end{array}$}} & \multicolumn{5}{|c|}{ Mode of Transport } & \multirow[b]{3}{*}{$\begin{array}{l}\text { Below } \\
5 \mathrm{~km}\end{array}$} & \multirow{2}{*}{\multicolumn{3}{|c|}{$\begin{array}{l}\text { Distance in Kilometers } \\
\text { Respondent in } \\
\text { Percentage }\end{array}$}} & \multirow[b]{3}{*}{$\begin{array}{l}20.1- \\
25 \mathrm{~km}\end{array}$} & \multirow[b]{3}{*}{$\begin{array}{l}25.1 \text { to } \\
30 \mathrm{~km}\end{array}$} \\
\hline & & & & & & & \multicolumn{2}{|c|}{$\begin{array}{c}\text { Respondents in } \\
\text { Percentage }\end{array}$} & \multirow[b]{2}{*}{$\begin{array}{l}\text { Motor } \\
\text { Cycle }\end{array}$} & \multirow[b]{2}{*}{ Ferry } & \multirow[b]{2}{*}{ Rail } & & & & & & \\
\hline & $\begin{array}{l}8 \cdot \\
12 \text { noon }\end{array}$ & $\begin{array}{l}12.01 \\
-5 \mathrm{pm}\end{array}$ & $\begin{array}{l}5.01 \mathrm{pm} \\
\text { and } \\
\text { later }\end{array}$ & $\begin{array}{l}8- \\
12 \text { noon }\end{array}$ & $\begin{array}{l}12.01 \\
-5 \mathrm{pm}\end{array}$ & $\begin{array}{l}5.01 \mathrm{pm} \\
\text { and } \\
\text { later }\end{array}$ & $\begin{array}{l}\text { Private } \\
\text { Vehicle }\end{array}$ & $\begin{array}{l}\text { Commercial } \\
\text { Vehicle }\end{array}$ & & & & & $\begin{array}{l}5.1- \\
10 \mathrm{~km}\end{array}$ & $\begin{array}{l}10.1 \text { to } \\
15 \mathrm{~km}\end{array}$ & $\begin{array}{l}15.1- \\
20 \mathrm{~km}\end{array}$ & & \\
\hline Agege & 23.12 & 47.93 & 28.95 & 10.12 & 17.43 & 72.45 & 30.41 & 52.89 & 6.70 & - & - & 10.82 & 13.79 & 15.98 & 25.42 & 18.25 & 15.76 \\
\hline Ojo & 32.41 & 55.23 & 12.36 & 12.32 & 19.12 & 68.56 & 32.24 & 64.72 & 3.04 & - & - & 16.43 & 18.12 & 20.02 & 19.89 & 14.34 & 11.20 \\
\hline Amuwo-odofin & 27.63 & 48.55 & 23.82 & 11.34 & 16.36 & 72.30 & 29.72 & 63.83 & 6.97 & - & - & 13.12 & 17.23 & 21.83 & 19.24 & 12.32 & 16.26 \\
\hline Alimosho & 29.39 & 46.35 & 24.26 & 09.12 & 10.21 & 80.67 & 36.12 & 62.12 & 1.06 & - & 0.70 & 20.42 & 16.73 & 18.42 & 13.89 & 14.89 & 16.16 \\
\hline Apapa & 36.12 & 46.87 & 17.01 & 15.01 & 21.31 & 63.68 & 42.13 & 58.31 & 0.35 & - & 0.09 & 19.89 & 20.97 & 20.81 & 19.42 & 8.26 & 10.56 \\
\hline Eti-osa & 41.10 & 46.44 & 12.46 & 11.40 & 13.22 & 75.38 & 29.42 & 64.13 & 3.23 & 3.22 & - & 15.10 & 13.82 & 22.31 & 17.28 & 16.38 & 15.11 \\
\hline Ifako-Ijaye & 39.87 & 44.41 & 15.72 & 13.12 & 14.13 & 72.75 & 31.33 & 60.89 & 7.78 & - & - & 30.12 & 23.43 & 12.42 & 10.83 & 12.42 & 10.78 \\
\hline Ikeja & 25.21 & 42.30 & 32.49 & 08.28 & 12.31 & 79.41 & 45.89 & 52.12 & 1.99 & - & - & 12.48 & 18.80 & 27.13 & 18.48 & 10.01 & 13.10 \\
\hline Kosofe & 40.24 & 46.19 & 13.57 & 13.13 & 17.40 & 69.47 & 29.73 & 63.44 & 6.83 & - & - & 21.01 & 18.91 & 22.33 & 22.14 & 09.06 & 06.55 \\
\hline Lagos Island & 18.62 & 53.40 & 27.98 & 10.39 & 12.31 & 77.30 & 48.38 & 50.36 & 1.26 & - & - & 18.20 & 25.43 & 23.16 & 10.26 & 10.61 & 12.35 \\
\hline Lagos Mariland & 15.88 & 54.86 & 29.26 & 12.81 & 11.39 & 75.80 & 43.26 & 52.83 & 3.91 & - & - & 13.42 & 14.44 & 32.11 & 18.42 & 10.03 & 11.58 \\
\hline Oshodi-Isolo & 39.87 & 32.64 & 27.49 & 10.09 & 13.97 & 77.94 & 25.27 & 64.17 & 3.30 & - & 7.26 & 19.83 & 14.93 & 17.26 & 27.22 & 08.62 & 12.14 \\
\hline Somolu & 32.73 & 47.45 & 19.82 & 12.99 & 12.08 & 74.93 & 31.10 & 63.84 & 8.78 & - & - & 17.43 & 19.19 & 19.87 & 23.12 & 10.12 & 10.27 \\
\hline Mushin & 43.20 & 54.44 & 11.36 & 12.41 & 13.12 & 74.47 & 29.88 & 66.41 & 3.71 & - & - & 20.01 & 18.39 & 21.43 & 12.16 & 13.09 & 14.92 \\
\hline Surulere & 36.83 & 35.74 & 27.43 & 09.82 & 11.78 & 78.40 & 32.47 & 60.81 & 6.72 & - & - & 23.21 & 15.12 & 17.82 & 16.79 & 16.42 & 10.64 \\
\hline
\end{tabular}


Table 4: Characteristics of Intra-City Shopping Trips in Lagos Metropolis

\begin{tabular}{|c|c|c|c|c|c|c|c|c|c|c|c|c|c|c|c|c|c|c|}
\hline \multirow{3}{*}{$\begin{array}{l} \\
\text { LOCAL } \\
\text { GOVERNMENT } \\
\text { AREAS } \\
\end{array}$} & \multirow{2}{*}{\multicolumn{3}{|c|}{\begin{tabular}{l|l} 
Departure Time & \\
Respondents in Percentage
\end{tabular}}} & \multirow{2}{*}{\multicolumn{3}{|c|}{$\begin{array}{l}\text { Arrival Time } \\
\text { Respondent in Percentage }\end{array}$}} & \multicolumn{5}{|c|}{ Mode of Transport } & \multirow[b]{3}{*}{ Rail } & \multirow{2}{*}{\multicolumn{3}{|c|}{$\begin{array}{l}\text { Distance in Kilometers } \\
\text { Respondent in } \\
\text { Percentage }\end{array}$}} & \multirow[b]{3}{*}{$\begin{array}{l}15.1- \\
20 \mathrm{~km}\end{array}$} & \multirow[b]{3}{*}{$\begin{array}{l}20.1- \\
25 \mathrm{~km}\end{array}$} & \multirow[b]{3}{*}{$\begin{array}{l}25.1 \text { to } \\
30 \mathrm{~km}\end{array}$} \\
\hline & & & & & & & \multicolumn{2}{|c|}{$\begin{array}{l}\text { Respondents in } \\
\text { Percentage }\end{array}$} & \multirow[b]{2}{*}{$\begin{array}{l}\text { Commercial } \\
\text { Vehicle }\end{array}$} & \multirow[b]{2}{*}{$\begin{array}{l}\text { Motor } \\
\text { Cycle }\end{array}$} & \multirow[b]{2}{*}{ Ferry } & & & & & & & \\
\hline & $\begin{array}{l}\text { Before } \\
\text { 12noon }\end{array}$ & $\begin{array}{l}1201 \\
\text { to } \\
4 \mathrm{pm}\end{array}$ & $\begin{array}{l}\text { 4.01pm } \\
\text { and } \\
\text { later }\end{array}$ & $\begin{array}{l}\text { Before } \\
\text { 12noon }\end{array}$ & $\begin{array}{l}12.01 \\
\text { to } \\
4 \mathrm{pm}\end{array}$ & $\begin{array}{l}\text { 4.01pm } \\
\text { and } \\
\text { later }\end{array}$ & $\begin{array}{l}\text { Private } \\
\text { Vehicle }\end{array}$ & $\begin{array}{l}\text { Official } \\
\text { Vehicle }\end{array}$ & & & & & $\begin{array}{l}\text { Below } \\
5 \mathrm{~km}\end{array}$ & $\begin{array}{l}5.1- \\
10 \mathrm{~km}\end{array}$ & $\begin{array}{l}10 \mathrm{to} \\
15 \mathrm{~km}\end{array}$ & & & \\
\hline Agege & 62.32 & 21.57 & 16.11 & 17.67 & 35.82 & 46.51 & 26.41 & 2.06 & 62.36 & 9.17 & - & - & 19.13 & 18.41 & 23.21 & 20.74 & 9.82 & 8.69 \\
\hline Ojo & 68.14 & 28.21 & 3.65 & 8.38 & 29.41 & 62.21 & 22.32 & 3.01 & 64.20 & 10.47 & - & - & 20.01 & 23.46 & 18.91 & 17.24 & 11.97 & 8.41 \\
\hline Amuwo-odofin & 70.32 & 20.82 & 8.86 & 10.28 & 24.39 & 65.33 & 27.68 & 1.10 & 62.82 & 8.40 & - & - & 18.87 & 20.32 & 24.72 & 21.37 & 8.27 & 6.45 \\
\hline Alimosho & 69.66 & 23.06 & 7.28 & 12.18 & 19.38 & 68.44 & 21.12 & 1.79 & 64.37 & 11.69 & - & 1.30 & 16.22 & 21.24 & 18.33 & 19.72 & 13.12 & 113.7 \\
\hline Apapa & 59.95 & 28.62 & 11.43 & 7.82 & 53.86 & 38.32 & 30.71 & 5.26 & 61.47 & 2,32 & - & 0.24 & 20.44 & 22.31 & 22.48 & 20.36 & 10.13 & 4.27 \\
\hline Eti-osa & 67.97 & 29.08 & 2.95 & 10.97 & 22.42 & 66.61 & 29.66 & 4.22 & 59.89 & 2.32 & 3.41 & - & 24.16 & 25.42 & 18.26 & 17.42 & 8.12 & 6.62 \\
\hline Ifako--ljaye & 71.12 & 18.79 & 10.09 & 10.72 & 21.79 & 67.49 & 20.88 & 3.13 & 63.01 & 12.98 & - & - & 18.23 & 20.71 & 24.42 & 26.33 & 7.13 & 3.18 \\
\hline Ikeja & 30.42 & 50.86 & 18.72 & 12.9 & 50.86 & 36.24 & 30.02 & 10.02 & 50.03 & 9.93 & - & - & 20.82 & 23.16 & 20.22 & 20.07 & 8.01 & 7.72 \\
\hline Kosofe & 73.01 & 18.82 & 8.17 & 13.41 & 18.49 & 68.10 & 19.82 & 6.02 & 63.09 & 11.07 & - & - & 18.76 & 20.42 & 19.33 & 21.82 & 10.33 & 9.34 \\
\hline Lagos Island & 32.56 & 57.79 & 9.65 & 11.20 & 58.92 & 29.88 & 31.33 & 18.28 & 50.22 & 0.17 & - & - & 19.12 & 21.11 & 20.17 & 22.51 & 9.12 & 7.97 \\
\hline Lagos Mariland & 65.41 & 29.93 & 4.97 & 4.62 & 32.46 & 62.92 & 30.12 & 19.01 & 45.10 & 5.77 & - & - & 19.87 & 20.22 & 23.14 & 23.66 & 8.31 & 4.80 \\
\hline Oshodi-Isolo & 75.66 & 15.84 & 9.10 & 11.80 & 19.91 & 69.01 & 20.42 & 09.10 & 65.82 & 3.16 & - & 1.50 & 21.06 & 23.52 & 25.03 & 17.44 & 8.22 & 4.73 \\
\hline Somolu & 74.89 & 16.57 & 8.54 & 12.28 & 18.41 & 69.31 & 19.13 & 11.12 & 67.75 & 2.00 & - & - & 17.21 & 20.80 & 2.26 & 24.13 & 9.79 & 5.81 \\
\hline Mushin & 73.43 & 18.66 & 7.91 & 12.33 & 20.21 & 67.46 & 17.81 & 10.31 & 65.86 & 6.02 & - & - & 19.01 & 22.11 & 23.16 & 23.55 & 10.28 & 1.89 \\
\hline Surulere & 69.81 & 24.88 & 5.31 & 16.25 & 27.77 & 55.98 & 21.42 & 15.89 & 60.88 & 1.81 & - & - & 20.10 & 20.42 & 24.36 & 23.01 & 7.08 & 5.03 \\
\hline
\end{tabular}


Table 5: Characteristics of Intra-City Recreation Trips in Lagos Metropolis

\begin{tabular}{|c|c|c|c|c|c|c|c|c|c|c|c|c|c|c|c|c|c|c|}
\hline & Departu & Time & & Arrival & ime & & & & de of Transpo & & & & Distan & in Kilon & ters & & & \\
\hline & Respon & ents in $\mathrm{P}$ & centage & Respo & dent in $\mathrm{P}$ & centage & $\begin{array}{r}\text { Resp } \\
\text { Per }\end{array}$ & $\begin{array}{l}\text { dents in } \\
\text { entage }\end{array}$ & & & & & $\begin{array}{l}\text { Respon } \\
\text { Percen }\end{array}$ & ant in & & & & \\
\hline $\begin{array}{l}\text { LOCAL } \\
\text { GOVERNMENT } \\
\text { AREAS }\end{array}$ & $\begin{array}{l}\text { Before } \\
\text { 12noon }\end{array}$ & $\begin{array}{l}12.01 \\
\text { to } 4 \mathrm{pm}\end{array}$ & $\begin{array}{l}\text { 4.01pm } \\
\text { and } \\
\text { later }\end{array}$ & $\begin{array}{l}\text { Before } \\
\text { 12noon }\end{array}$ & $\begin{array}{l}1201 \\
\text { to } 4 \mathrm{pm}\end{array}$ & $\begin{array}{l}\text { 4.01pm } \\
\text { and } \\
\text { later }\end{array}$ & $\begin{array}{l}\text { Private } \\
\text { vehicle }\end{array}$ & $\begin{array}{l}\text { Official } \\
\text { vehicle }\end{array}$ & $\begin{array}{l}\text { Commercial } \\
\text { vehicle }\end{array}$ & $\begin{array}{l}\text { Motor } \\
\text { cycle }\end{array}$ & Ferry & Rail & $\begin{array}{l}\text { Below } \\
5 \mathrm{~km}\end{array}$ & $\begin{array}{l}5.1- \\
10 \mathrm{~km}\end{array}$ & $\begin{array}{l}10 t_{0} \\
15 \mathrm{~km}\end{array}$ & $\begin{array}{l}15.1- \\
20 \mathrm{~km}\end{array}$ & $\begin{array}{l}20.1- \\
25 \mathrm{~km}\end{array}$ & $\begin{array}{l}25.1 \text { to } \\
30 \mathrm{~km}\end{array}$ \\
\hline Agege & 37.36 & 45.48 & 17.16 & 09.12 & 15.06 & 75.82 & 29.41 & 6.22 & 59.82 & 4.55 & & & 11.42 & 13.04 & $\begin{array}{l}116.2 \\
8\end{array}$ & 26.31 & 18.45 & 14.50 \\
\hline Ojo & 30.89 & 49.32 & 19.79 & 12.01 & 13.52 & 74.47 & 31.11 & 6.21 & 60.43 & 2.25 & & & 12.04 & 14.51 & 19.36 & 24.08 & 17.26 & 12.75 \\
\hline Amuwo-odofin & 32.77 & 46.66 & 20.57 & 06.22 & 10.43 & 83.35 & 29.87 & 5.04 & 62.37 & 2.72 & & & 12.89 & 16.41 & 19.28 & 23.22 & 11.32 & 16.88 \\
\hline Alimosho & 30.42 & 42.97 & 26.61 & 12.31 & 16.04 & 71.65 & 29.63 & 4.36 & 63.04 & 1.65 & & 1.32 & 14.26 & 16.33 & 20.21 & 24.82 & 14.01 & 10.37 \\
\hline Apapa & 40.01 & 43.22 & 16.77 & 09.11 & 13.26 & 77.63 & 32.41 & 5.21 & 59.43 & 1.23 & & 1.72 & 13.11 & 15.45 & 19.89 & 24.36 & 10.04 & 17.15 \\
\hline Eti-osa & 41.33 & 43.11 & 15.56 & 10.01 & 12.66 & 77.33 & 26.11 & 5.06 & 60.12 & 3.29 & 5.42 & & 16.32 & 2.11 & 20.06 & 22.09 & 12.31 & 8.11 \\
\hline Ifako-liaye & 38.12 & 44.52 & 17.36 & 10.08 & 13.22 & 76,70 & 28.21 & 4.89 & 64.82 & 2.08 & & & 11.78 & 13.42 & 18.92 & 23.68 & 18.12 & 14.08 \\
\hline Ikeja & 43.20 & 45.12 & 11.68 & 11.32 & 18.04 & 70.64 & 30.01 & 11.32 & 55.07 & 3.60 & & & 16.82 & 20.01 & 21.23 & 25.07 & 10.58 & 6.29 \\
\hline Kosofe & 39.56 & 41.43 & 19.01 & 13.11 & 16.89 & 70.00 & 26.82 & 5.22 & 62.88 & 4.08 & & & 15.09 & 15.32 & 18.47 & 23.89 & 19.21 & 8.02 \\
\hline Lagos Island & 40.21 & 43.04 & 16.75 & 08.12 & 13.42 & 78.46 & 29.07 & 12.11 & 56.43 & 2.39 & & & 18.42 & 20.11 & 21.12 & 21.56 & 08.72 & 10.07 \\
\hline Lagos Mariland & 41.32 & 42.88 & 15.80 & 10.36 & 13.04 & 76.60 & 30.04 & 10.02 & 58.32 & 1.62 & & & 17.31 & 19.59 & 23.01 & 23.79 & 06.39 & 9.91 \\
\hline Oshodi-Isolo & 37.44 & 40.12 & 22.44 & 13.71 & 15.38 & 70.91 & 27.13 & 4.03 & 61.35 & 3.27 & & 4.22 & 13.42 & 14.89 & 20.12 & 20.56 & 17.34 & 13.67 \\
\hline Somolu & 32.31 & 39.42 & 28.27 & 12.66 & 17.52 & 69.82 & 28.81 & 3.89 & 63.11 & 4.19 & & & 11.16 & 15.45 & 22.11 & 19.34 & 18.10 & 13.84 \\
\hline Mushin & 34.14 & 38.22 & 27.64 & 12.13 & 15.05 & 72.82 & 28.19 & 4.01 & 64.22 & 3.58 & & & 15.12 & 14.82 & 21.01 & 23.33 & 14.69 & 11.03 \\
\hline Surulere & 34.02 & 39.34 & 26.64 & 11.41 & 13.67 & 74.92 & 26.12 & 3.22 & 65.54 & 4.12 & & & 13.03 & 13.79 & 20.22 & 24.09 & 15.84 & 13.00 \\
\hline
\end{tabular}

